\title{
DISPUTE RESOLUTION PROVISIONS OF THE AGREEMENT ON INTERNAL TRADE
}

\section{LUIGI Di MARZO•}

The author discusses the new Agreement on Internal Trade, a multilateral trade agreement to which the federal government and all the provincial governments in Canada are parties. The Agreement can also extend to municipal governments and any qualifying 'persons' in certain circumstances. The object of the Agreement is to remove barriers to the free movement of persons, goods, services and investment within Canada.

This article concentrates on the dispute resolution provisions of the Agreement The article is organized into three parts: the main characteristics of these provisions, how they operate for different entities and an assessment of the provisions.

The Agreement prescribes alternative dispute resolution in an effort to avoid the length and cost of traditional court settlements. It has dispute resolution provisions in two places: for each industry in its respective sector chapter and for general application in chapter 17. While the provincial and federal governments may use the dispute resolution provisions directly as needed, non-parties to the Agreement who wish to make use of the provisions may do so only if a government with which they have a "substantial connection" initiates proceedings on their behalf, or after passing a screening process.

The article reviews each step of the process that must be made in order to resolve disputes under the Agreement, both for government-10-government and person-to-government disputes. The article ends with an assessment of the dispute resolution provisions and some suggested improvements to them that may have improved and streamlined the provisions, especially for person-to-government disputes.
L'auteur examine le nouvel accord de commerce intérieur, un accord multilatéral signé par le gouvernement fédéral et toutes les provinces du Canada. Cet accord peut aussi s'étendre aux administrations municipales $e t$, dans certaines circonstances, aux «personnes» admissibles. Il vise à éliminer les obstacles à la libre circulation des personnes, des biens, des services et des investissements à l'intérieur du Canada.

Cet article, axé sur les dispositions de résolution des différends contenues dans l'accord, compte trois parties : les caractéristiques majeures des dispositions, la facon dont elles fonctionnent pour différentes entités et une évaluation des dispositions.

$L$ 'accord prescrit des solutions de rechange en vue d'éviter la durée et le coût des règlements judiciaires traditionnels. Les dispositions se trouvent à deux endroits : au chapitre propre à chaque industrie et au chapitre 17 traitant d'application générale. Bien que les gouvernements fédéral et provinciaux puissent utiliser ces dispositions directement selon leurs besoins, les tiers ou nonparties à l'accord ne peuvent y recourir que si un gouvernement avec qui elles ont des liens importants engage des procédures en leur nom, ou après avoir subi une sélection préliminaire.

$L$ 'article retrace chaque étape du processus $\dot{a}$ suivre en vue de résoudre les différends - entre gouvernements d'une part, et entre gouvernements et particuliers d'autre part. Il se termine par une évaluation des dispositions sus-mentionnées et suggère certaines modifications visant $\dot{a}$ les améliorer et à les simplifier, surtout en matière de différends opposant personnes et gouvernements.

\section{TABLE OF CONTENTS}

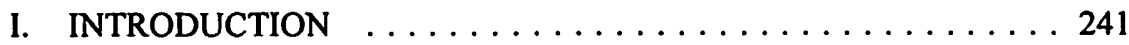

II. PART ONE: CHARACTERISTICS OF DISPUTE SETTLEMENT PROCEDURES $\ldots \ldots \ldots \ldots \ldots \ldots \ldots \ldots 242$

Luigi Di Marzo was Director of the Office of Internal Trade, with the Alberta Federal and Intergovernmental Affairs Department, and Chairman of the Energy Negotiating Table during negotiation of the Agreement. He is now a consultant and principal of DiMarzo and Associates. The views expressed in this article are solely those of the author and are not to be attributed to the Government of Alberta. 

A. ALTERNATIVE DISPUTE RESOLUTION -
NO INVOLVEMENT BY COURTS . . . . . . . . . 242
B. GOVERNMENTS HAVE PRIMARY ROLE;
PRIVATE SECTOR INVOLVEMENT LIMITED . . . . . . 243
C. DOUBLE PROCESS - INITIATION

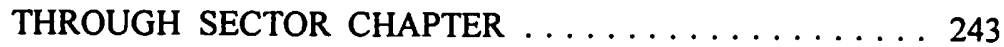
D. LIMITED ENFORCEMENT $\ldots \ldots \ldots \ldots \ldots \ldots \ldots \ldots 245$

III. PART TWO: HOW THE DISPUTE RESOLUTION

PROCEDURES WORK .................. 245
A. GOVERNMENT-TO-GOVERNMENT
DISPUTE RESOLUTION ................. 246

B. PERSON-TO-GOVERNMENT DISPUTE RESOLUTION . 256

IV. PART THREE: ASSESSMENT OF DISPUTE

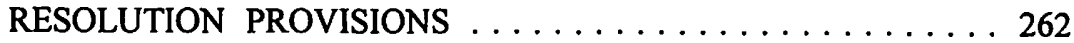

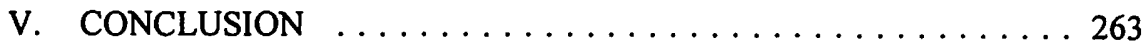

\section{INTRODUCTION}

The Agreement on Internal Trade, ${ }^{1}$ which came into force on July 1, 1995 is a landmark agreement.

First, it is the most comprehensive trade agreement concluded in Canada to date. Until now, trade agreements have been limited to the trade in goods or to particular sectors of the economy. While the Agreement is not as comprehensive as some jurisdictions had wanted, its objective is to remove barriers to the free movement of persons, goods, services and investment within Canada. ${ }^{2}$ It does so by covering eleven of the most important areas of the Canadian economy in its sector chapters. ${ }^{3}$

Second, it is the only multilateral trade agreement to which all Canadian governments are parties. Until this agreement was concluded, most agreements were either bilateral or regional. In contrast, all governments - federal, provincial and territorial - are parties to the Agreement. To a limited extent, the Agreement even extends to municipal governments, since each party is responsible for compliance with the Agreement by its regional, local or other forms of local government where provided for in the Agreement. ${ }^{4}$

1 Agreement on Internal Trade, 18 July 1994 (signed by the government of Canada, all the provincial and both territorial governments) [hereinafter Agreement].

2 See art. 100 of the Agreement, ibid, which states that the objective of the parties is to "reduce and eliminate, to the extent possible, barriers to the free movement of persons, goods, services and investments within Canada and to establish an open, efficient and stable domestic market."

3 These chapters deal with procurement, investment, labour mobility, consumer-related measures and standards, agricultural and food-related goods, alcoholic beverages, natural resources processing, transportation, communications and environmental protection. Energy is also supposed to be covered by the Agreement, but the parties have yet to negotiate the provisions of the energy chapter.

4. See supra note 1, art. 102 on Extent of Obligations. 
Third, it is the first trade agreement in Canada that has extensive provisions on dispute resolution, and it is the first to grant private persons ${ }^{5}$ a role, albeit a limited one, in dispute resolution procedures.

This article concentrates on the dispute resolution provisions of the Agreement. It is organized into three parts:

- Part One outlines the main characteristics of the provisions;

- Part Two explains how the provisions operate, and points out how they can be used by both government officials and members of the private sector;

- Part Three assesses the provisions.

\section{PART ONE: \\ CHARACTERISTICS OF DISPUTE SETTLEMENT PROCEDURES}

The Agreement contains two sorts of dispute resolution provisions: general provisions found in chapter 17, and specific provisions found in the sector chapters which make up Part IV of the Agreement. In aggregate, the provisions are lengthy and complex. There is no easy buzzword to describe them. They can best be described as a hybrid which has the following characteristics:

- Alternative dispute resolution - no involvement by the courts;

- Government has the primary role; limited private sector involvement;

- Initiation through sector chapters;

- Limited enforcement.

\section{A. ALTERNATIVE DISPUTE RESOLUTION - NO INVOLVEMENT BY COURTS}

Despite the many differences among the parties during negotiations, they were agreed on two things. First, disputes should be resolved in a conciliatory, cooperative, and harmonious manner. This is clearly stated in the lead article of chapter 17, which states that the parties shall

make every attempt through cooperation, consultations and other dispute avoidance and resolution processes available to them to arrive at a mutually satisfactory resolution of any matter that may affect the operation of this Agreement. ${ }^{6}$

In essence, the parties are convinced that since enough good will exists among them, the best way to resolve disputes is to continue the negotiating process and resolve problems through consultations wherever possible.

5 See ibid. art. 200 (Definitions): Persons means "a natural person or an enterprise." Art. 1711.6 adds that for the purposes of dispute resolution, a person "includes a trade union as recognized by the applicable legislation of a Party."

$6 \quad$ Ibid., art. 1700.2. 
Second, it is agreed that the outcome of disputes should not be determined by the courts. Many of the governments were disappointed with how courts interpreted intergovernmental agreements in the past and they were wary of how they would do so in the future. Therefore, they agreed that every effort must be made to avoid the courts and settle disputes through alternative dispute resolution processes (ADR). If an appeal of a decision was required, the appeal should be handled through executive federalism. In essence, the Committee on Internal Trade, composed of cabinet-level representatives of each party, would be the final body of appeal.

The Agreement is therefore clear that disputes are to be resolved through alternative dispute resolution (ADR) processes. The primary instrument for solving disputes is consultations. The most formal legal mechanism is the establishment of a panel to conduct an arbitration.

\section{B. GOVERNMENTS HAVE THE PRIMARY ROLE; PRIVATE SECTOR INVOLVEMENT IS LIMITED}

While both governments and the private sector can be involved in dispute resolution, governments play the primary role. The rationale for this is that governments are parties to the Agreement. In addition, historically, governments alone have played a role in resolving disputes arising from intergovernmental agreements.

Substantial discussion took place during negotiations about the role of the private sector in dispute resolution. Some jurisdictions, led by Alberta and Canada, wanted the private sector to have a role similar to governments. Other jurisdictions, led by Saskatchewan, Ontario and British Columbia, strongly opposed granting the private sector any status and stated that they did not want to be harassed by the private sector. Most jurisdictions were prepared to grant the private sector a role but wanted it clearly circumscribed.

The result is that the private sector can be involved in dispute resolution directly, or indirectly by having a government initiate proceedings on its behalf. In either case this role this can be played only after review and screening by a government agency. Private sector challenges are restricted to asking for a determination of whether an actual measure is inconsistent with the Agreement.

\section{DOUBLE PROCESS - INITIATION THROUGH SECTOR CHAPTER}

Although chapter 17 contains general dispute resolution provisions, the Agreement in effect contains two processes. Dispute resolution is to be initiated under the auspices of one of the sector chapters. Only after the process outlined in the sector chapter is exhausted can the general dispute resolution provisions be pursued.

This process reflects several factors. First, two contrasting views on the architecture of the Agreement and the relationship among chapters existed during negotiations. On the one hand, some jurisdictions suggested that the Agreement should be rules-based and comprehensive, encompassing every sector of the economy unless it was 
specifically excluded. In essence, the parties supporting this view wanted to pursue negotiations by first adopting the general rules and then identifying the matters to which they would not apply. The presumption was that a matter would be subject to the Agreement unless excluded. Proponents of this view advocated adopting effective, general dispute resolution procedures which would apply to all matters covered by the Agreement.

On the other hand, some jurisdictions suggested that the Agreement should consist only of principles which would be guidelines for action. The Agreement should be limited in scope and apply only to those items specifically included. The parties supporting this view wanted to pursue negotiations by first adopting rules for individual sectors and then generalizing them. The presumption was that unless a matter was specifically included, the Agreement would not apply to it. Proponents of this view argued that the Agreement required only guidelines for amicably resolving disputes and not detailed dispute settlement procedures since the "rules" themselves were only to be guidelines. If rules for dispute resolution were to be developed, that should be done at the sector level. If a dispute arose, resolution should be attempted at the sector level. Only after sector procedures were exhausted should the general procedures be initiated.

Second, negotiation of the Agreement simultaneously took place at the general and the sector level. It was originally envisaged that negotiations for all matters would be conducted by chief negotiators representing each jurisdiction, who would report to the Council of Ministers of Internal Trade. It was further envisaged that a number of working groups, including one on dispute resolution, would be appointed and would report to and be under the tight guidance of the chief negotiators.

Soon after negotiations began and the contrasting viewpoints became evident, however, this process was altered with dramatic effect. The jurisdictions who suggested that the Agreement should consist only of guidelines argued that if rules were to be developed, it should be done in each sector and then generalized. They forcefully argued that a parallel, concurrent series of negotiations be undertaken for each sector. A series of sector negotiating tables responsible for negotiating each sector chapter was therefore established.

This structure resulted in interesting negotiating dynamics. The chief negotiators established a working group to develop the dispute resolution provisions. At the same time, each sector negotiating group was entrusted with developing all provisions, including those on dispute resolution. In some situations, the sector tables developed dispute resolution mechanisms without waiting for the general guidelines. In other cases, the tables awaited the general guideline from the chief negotiators.

Toward the end of negotiations it was not clear which provisions, the general or the sector ones, would prevail. To clarify matters, the chief negotiators decided that the process should begin in chapter 17 . There, the disputants would have to choose a sector chapter under which to proceed and follow its procedures. Only after exhausting the process outlined in the chosen sector chapter could the disputants come back to chapter 17 and follow the general procedures. 


\section{LIMITED ENFORCEMENT}

Given that disputes are for the most part to be resolved through alternative dispute resolution processes, enforcement is not a critical issue except for panel decisions.

There was considerable discussion at the negotiating table on how to ensure compliance with panel decisions. Consideration was given to retaliation, imposing fines, awarding damages, referral to courts and publicity. In the end, a rather minimalist position was adopted. Enforcement is restricted to two major actions: publicizing the offending measure and taking retaliatory action. In cases where the private sector initiates a case, publicity is the only means of enforcement.

\section{PART TWO: HOW THE DISPUTE RESOLUTION PROCEDURES WORK}

A practitioner wanting to pursue the dispute resolution process would begin with chapter 17 of the Agreement. It outlines the whole process, starting with the application of the procedures. It states simply that the procedures apply "to the avoidance and resolution of disputes, between Parties, or persons and Parties, regarding the interpretation or application of the Agreement." ${ }^{7}$ It is to be noted that the procedures apply generally to the avoidance and resolution of disputes regarding the interpretation and application of the Agreement, but in different ways, depending on who is the disputant. Under the Agreement, two types of disputants, governments and persons, are recognized.

The procedures to be followed by governments are specified under Part A: Government-to-Government Dispute Resolution. Those for persons are specified under Part B: Person-to-Government Dispute Resolution. Part B, in fact, contains two sorts of procedures: those to be followed when a goverrment takes up a case on behalf of a person, and those to be followed when the person acts on his own behalf.

For illustrative purposes I will first discuss the procedures to be followed in government-to-government dispute resolution and then compare these to the procedures to be followed in person-to-government dispute resolution. The procedures for both types of disputes, however, are similar in all but three respects:

- while governments may engage in dispute resolution directly, private persons can do so only after being subjected to a screening process.

Ibid., art. 1701.1 states that "Subject to paragraph 6, this chapter applies to the avoidance and resolution of disputes between Parties, or persons and Parties, regarding the interpretation or application of this Agreement." Para. 6 in effect says that the procedures for initiating disputes outlined in chapter 17 do not apply to procurement. It states that arts. 1702 through 1708 do not apply to bid protests initiated under art. 513 (Bid Protest Procedure - Provinces). Arts. 1711 through 1720 do not apply to bid protests initiated under art. 514 (Bid Protest Procedure Federal Government). 
- while governments can seek resolution of disputes involving actual and prospective measures, and any other matter, private persons can only seek resolution concerning actual measures.

- while governments can take retaliatory action for non-implementation of a panel decision by a party, enforcement of private person disputes is limited to publicizing the case.

\section{A. GOVERNMENT-TO-GOVERNMENT DISPUTE RESOLUTION}

Government-to-government dispute resolution is presumed to be the norm in the Agreement because governments are the parties to the Agreement. In addition, governments alone have historically had a role in resolving disputes arising from intergovernmental agreements. It appears, however, that the terminology "governmentto-government" is merely a descriptive handle. The Agreement does not define "government" for the purposes of dispute resolution and after using "government" in the caption, it switches to the term "Party" or "Parties" to describe disputants.

Procedurally, the Agreement appears to require disputants to go through four steps (see Figure 1):

- Initiation of procedures: The parties are first required to follow chapter 17 to initiate procedures.

- Follow sector chapter procedures: The parties are then required to follow and exhaust the procedures outlined in the chosen sector chapter.

- Follow chapter 17 procedures: If, having followed the sector chapter procedures, the dispute has not been resolved, the disputant may come back to chapter 17 and follow its procedures.

- Implementation and Enforcement: Lastly, the parties can initiate procedures for implementing and enforcing panel reports when a government does not comply with the decision. 


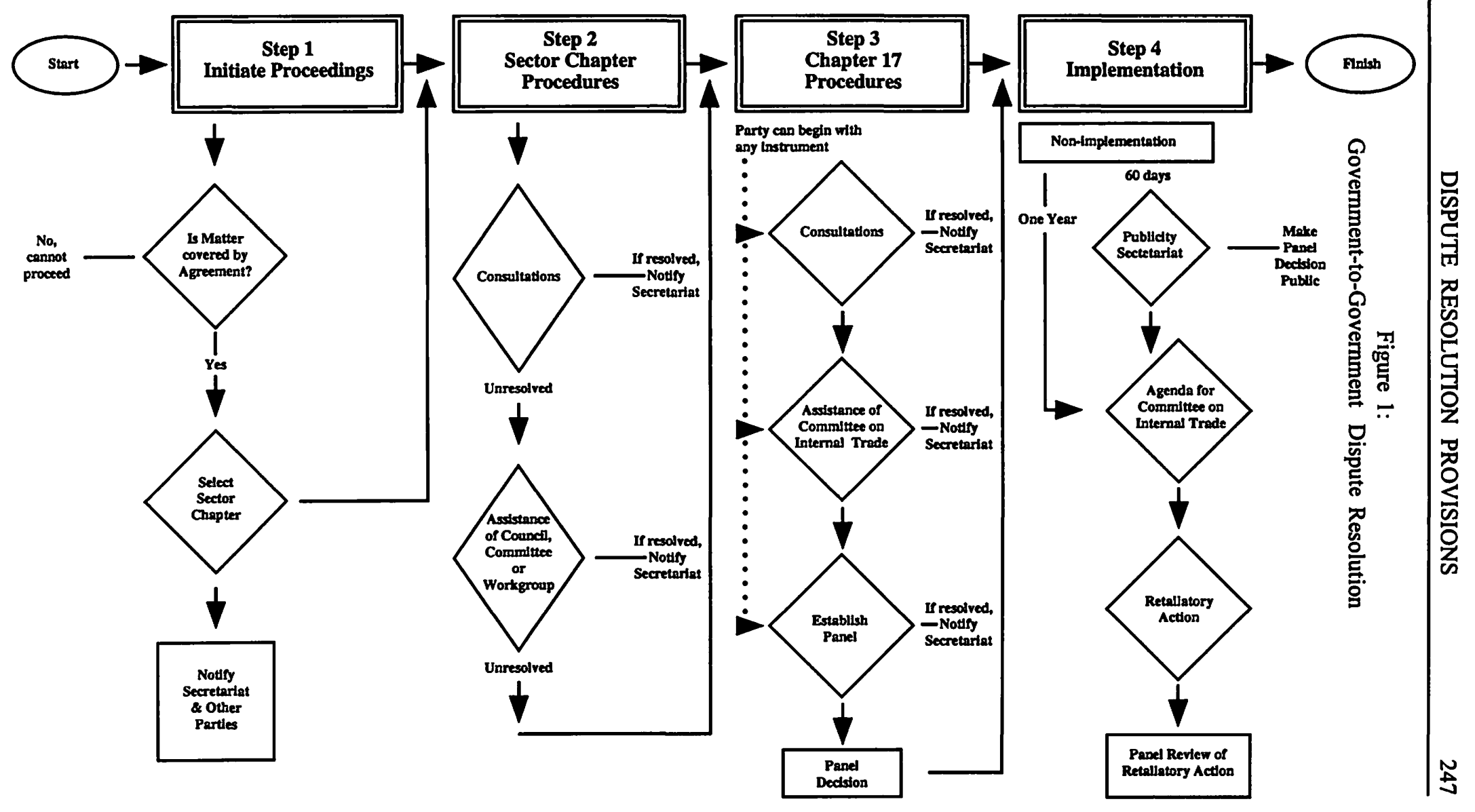




\section{Step 1: Initiation of Procedures}

Before a party initiates dispute resolution proceedings it must perform three preliminary tasks. It must first establish whether the item in contention is covered by the Agreement. Second, it must decide under which sector chapter to commence proceedings. Third, it must notify the party complained against and the Internal Trade Secretariat of the selection of the applicable chapter and of the matter.

a. Is the item covered by the Agreement?

Determining whether an item is covered will require careful scrutiny of the Agreement. The presumption is that unless a matter is specifically included, it is not covered by the Agreement. But how does one determine what is covered?

One can begin by noting that structurally the Agreement consists of eighteen separate chapters divided into six parts. Seven of the chapters, comprising parts I - III and parts V-VI, are general chapters. They deal with operating principles, general definitions, constitutional authorities, general rules, institutional provisions, dispute resolution and other general provisions.

Eleven chapters, comprising Part IV of the Agreement, cover the following specific sectors:

- procurement

- investment

- labour mobility

- consumer-related measures and standards

- agricultural and food-related goods
- alcoholic beverages

- natural resources processing

- energy

- communications

- transportation

- environmental protection

With this structure in mind, there are several steps one can take:

- Review the sector chapters, especially the provisions in each on scope and coverage, to determine what they cover. This is an essential step, since the Agreement applies to a matter only if it is covered by a sector chapter.

- Review the sector chapters to determine what is excluded.

- Review the general chapters, especially chapter 18 , to establish what has been generally excluded or exempted from the rules.

- Lastly, review the provisions in the Agreement on legitimate objectives. ${ }^{8}$ Even 
if it is established that a measure is inconsistent with the general rules, it is still permissible if it can be demonstrated that its purpose is to achieve a legitimate objective.' A lot of time fruitlessly challenging these types of measures can be avoided if legitimate objectives are identified at the beginning.

\section{b. Choosing a Chapter under which to Proceed}

Before initiating proceedings under chapter 17, Part A, a party must select and proceed under a sector chapter in Part IV of the Agreement. ${ }^{10}$ Only where a chapter, such as chapter 13 on Communications, contains no dispute avoidance or resolution procedures, can a party proceed directly under chapter 17 .

How does one choose a chapter? Two factors should be kept in mind. First, there are two types of sector chapters. "Some are "horizontal." While these are sector chapters, their rules apply within the scope of that particular chapter and, where applicable, to matters that fall within the scope of a vertical chapter. The horizontal chapters are those on Procurement, Investment, Labour Mobility, Consumer Related Measures and Standards, and Environment Protection.

In contrast, some chapters are "vertical." Their rules apply only to matters within the chapter in question. The vertical chapters are those on Agricultural and Food Goods, Alcoholic Beverages, Natural Resources Processing, Energy, Communications and Transportation.

Second, the rules of interpretation state that in the event of an inconsistency between a vertical and a horizontal chapter, the vertical chapter prevails to the extent of the inconsistency, except as otherwise provided.

There is no easy way of deciding whether to begin in a vertical or horizontal chapter in cases where a measure falls under both. It is really a strategic question. If the objective is to question a measure in a specific sector only, for instance residency requirements for truck licensing, then a vertical chapter may do. However, if the

(b) the measure does not operate to impair unduly the access of persons, goods, services or investments of a Party that meet that legitimate objective;

(c) the measure is not more trade restrictive than necessary to achieve that legitimate objective; and

(d) the measure does not create a disguised restriction on trade.

For the definition of legitimate objectives, see ibid., art. 200 (General Definitions). It is rather open-ended and includes objectives such as public security and safety; public order; protection of human, animal or plant life or health; protection of the environment; consumer protection; protection of the health, safety and well-being of workers; or affirmative action programs for disadvantaged groups.

Ibid., art. 1701.2 states that:

Before a Party initiates dispute resolution proceedings under Part A of the Chapter, it shall select and proceed only under the one chapter in Part IV of this Agreement that it considers to be the most applicable to the matter [emphasis added].

"See ibid., Annex 1813 on Rules of Interpretation. 
objective is to question a similar measure that applies to several sectors, for instance a residency requirement in several areas, then a horizontal chapter may be preferable. Before initiating an action, a government would have to carefully decide how to characterize the measure, determine what outcome it wanted, and assess the chances of obtaining its desired result through either a vertical or horizontal chapter.

\section{c. Notification of Other Party and Secretariat}

Having determined that a matter is covered by the Agreement, and having chosen a sector chapter under which to proceed, a complaining party must deliver notice to the party complained against and the secretariat of the selection of the applicable chapter and of the matter.

The other side of this requirement is that "[i]f the disputing Parties resolve the dispute at any stage, written notice of such resolution must be delivered to the other Parties and the Secretariat." 12

\section{Step 2: Using Procedures in Sector Chapters}

Having decided under which sector chapter to proceed, a party must then follow the procedures in that chapter. This step is not a mere formality. The Agreement wording is forceful in urging the parties to attempt to resolve the matter using the procedures in the applicable chapter, and in stating that "[s]uch a process must be exhausted before a complaining Party may proceed to dispute resolution under [chapter 17]."13

What do the sector chapters say? In Table 1, which summarizes the sector chapter provisions, it will be seen that provisions differ on details but they have several common features:

- Consultations appear to be the main instrument for handling disputes. Eight of the chapters contain provisions on consultations. Only a few chapters contain provisions for mediation or conciliation. The procurement chapter which contains elaborate bid-protest procedures is the only one that establishes panels. The energy chapter is not yet available, but indications are that it will also contain provisions on consultations and mediation. The communications chapter contains no dispute resolution procedures.

- Most chapters contain mechanisms to help parties solve disputes. These either refer disputes to, or ask the assistance of, a council of Ministers, a committee or a working group in resolving disputes. The councils of Ministers identified in the chapters all existed before the Agreement was concluded. Most of the working groups and committees, however, are creations of the Agreement. 
The hope and expectation of the parties is that disputes will be settled at the sector level. However, in the event that no resolution is possible, most chapters contain specific provisions outlining the point at which chapter 17 procedures can be initiated. This is usually sixty to ninety days from the date the request for consultations was made. At this point, the complaining party can claim to have exhausted the process at the sector level and proceed to chapter 17.

\section{Step 3: Chapter 17 Procedures}

If the dispute is not resolved at the sector level, the parties may come back to chapter 17 and follow its procedures. The parties are given three alternatives for solving disputes: consultations, requesting the assistance of the Committee on Internal Trade, and establishment of a panel.

How should a party proceed? Which alternative should it choose? The decision depends on the strategy it wants to follow, but several things should be considered:

- Although a party may start with any alternative, the sequence envisioned by the chapter is consultations, followed by a request for assistance of the Committee on Internal Trade, and then establishment of a panel. Consequently, if a party starts with consultations, it retains two other options; but if it starts with the request to strike a panel, it has played its last card.

- A party to a dispute will already have engaged in consultations at the sector level. If it begins with consultations again it risks involving more parties, and hence prolonging the dispute. Under chapter 17 procedures, any party that has a substantial interest in the matter may participate in the consultations. ${ }^{14}$ It appears that further consultations would be of benefit only to a defending party which wants to stall.

All things considered, unless a party is defending an action, it should skip consultations and proceed directly to seeking the assistance of the Committee or to establishing a panel.

\section{a. Consultations}

Consultations appear to be provided as an alternative in order to give parties who went through the sector processes another opportunity to discuss matters. It is also provided for cases where the applicable sector chapter contains no dispute avoidance or resolution process and a complaining party is required to proceed directly to dispute resolution under chapter 17.

Consultations may be launched by either disputing party, by delivering a written notice to all other parties and the Secretariat. Notifying all other parties appears to be 
cumbersome, but it is required, since any party which has a substantial interest in the matter may participate in consultations. According to Article 1704.10, a party shall be deemed to have a substantial interest in the matter in dispute where:

a) In the case of any party, it maintains a measure that is analogous to the one at issue; or

b) In the case of a party that is a province, it has a significant number of persons carrying on a business in the province who are or will be affected by the measure or issue.

Consultations shall begin within ten days after the date of delivery of the request, and are to be confidential and without prejudice to the right of further proceedings.

\section{b. Assistance of Committee on Internal Trade}

The Committee on Internal Trade is the principal institution established under the Agreement. ${ }^{15}$ The committee is composed of cabinet-level representatives, or their designates, of each of the parties. Two of its main functions are to supervise the implementation of the Agreement and to assist in the resolution of disputes arising from it.

The Committee's assistance can be sought in four circumstances when the matter in dispute has not been resolved to the satisfaction of the disputing parties: ${ }^{16}$

- within thirty days of the processes in the sector chapters being exhausted;

- within thirty days of notice being given to proceed directly to seek the assistance of the Committee;

- within forty days after the date of delivery of the request for consultations;

- within such other period of time as the disputing parties may agree.

Either disputing party may make a written request to the Committee. The requesting party must itemize the matter complained about and provide a brief summary of the complaint. It must also deliver a copy of the request to the other parties and the Secretariat. The Committee is required to convene within twenty days after the delivery of the request and to provide assistance to the disputing parties.

Should a disputant seek the assistance of the Committee? The answer is yes, in theory. Engaging the Committee provides the best prospect for resolving the dispute since the Committee involves all the major decisions-makers in Canada. In addition, the Committee is capable of providing assistance in five ways, by: ${ }^{17}$ 
a) consulting with the committee or council of Ministers or working group that provided assistance under a sector chapter;

b) seeking the advice of technical experts;

c) establishing working groups or fact-finding bodies;

d) facilitating the use of conciliation, mediation and other dispute resolution mechanisms;

e) making recommendations.

However, a party must also take into account that the Committee is a political body and depending on the circumstances, may be reluctant to make a firm decision. Its composition, consisting of cabinet level representatives, suggests that it may be difficult to quickly arrange a meeting of its members.

\section{c. Establishing a Panel}

Establishing a panel to conduct an arbitration is the final step for dispute resolution. ${ }^{18}$ Any disputing party may, after all the other processes have been exhausted, make a written request to the Committee for the establishment of a panel. The request may be made either by the party for itself, or by the complaining party on behalf of a person.

The panel shall be composed of five members, chosen from a roster of panelists maintained by the parties. ${ }^{19}$ Each disputing party shall appoint two panelists from the roster who were not nominated by that party. ${ }^{20}$ The fifth panelist, the chairperson, is to be selected by the appointed panelists from the roster. ${ }^{21}$ If the appointed panelists cannot agree on a chair, the Secretariat shall select the chairperson by lot from the roster. ${ }^{22}$

The terms of reference of the panel shall, unless the disputing parties otherwise agree, be "to examine whether the actual or proposed measure or other matter at issue is or would be inconsistent with the Agreement." ${ }^{23}$ The panel is to be guided by rules of procedure. ${ }^{24}$

Any party that has a substantial interest in the matter in dispute is entitled to join the panel proceedings on delivery of a written notice to the other parties and the Secretariat. This right to participate is a double-edged sword. It entitles the party to

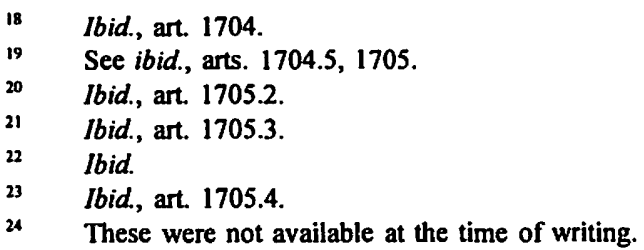


participate in the proceedings. It also has the effect, however, of making any recommendation made by the panel with regard to making a measure consistent with the Agreement apply in relation to that party. ${ }^{25}$

The panel is obliged to write a report within forty-five days of the hearing being completed. ${ }^{26}$ The report shall contain:

a) findings of fact;

b) a determination, with reasons, as to whether the measure in question is or would be inconsistent with the Agreement;

c) a determination, with reasons, as to whether the measure in question has impaired or would impair internal trade and has caused or would cause injury;

d) recommendations, if requested by a disputing Party, to assist in resolving the dispute. ${ }^{27}$

If a party has been unable to resolve a dispute through all the other means, it should certainly ask for the establishment of a panel. The panel is impartial and it must make a decision one way or the other on the questions put to it. It would be one of the clearest ways to obtain guidance on whether a matter is or is not consistent with the Agreement.

\section{Step 4: Implementation of Panel Report and Enforcement}

In keeping with the desire to solve disputes through alternative mechanisms and to avoid the courts, the Agreement contains modest enforcement provisions.

The Agreement states that wherever possible, resolution of the dispute shall be the non-implementation, removal or amendment of the measure that is inconsistent with the Agreement. ${ }^{28}$ In the case of panel reports, disputing parties shall comply with the recommendations within sixty days or agree on a mutually satisfactory resolution of the dispute. $^{29}$

What happens if a party does not comply with the recommendations of the panel or the suggested solution is not mutually satisfactory? The Agreement provides for two remedies: publicity and retaliatory action. Publicity consists of the Secretariat making the panel report public and adding the matter to the agenda of the Committee on 
Internal Trade, for its annual meetings. ${ }^{30}$ The matter shall remain on the Committee's agenda until it is resolved.

Retaliatory action is the other remedy. While it is permitted under the Agreement, before taking retaliatory action a party must wait until one year after the issuance of a panel report. ${ }^{31}$ In addition, the party must follow procedures and its actions are subject to supervision and notable constraints:

- The complaining party must request a meeting of the Committee to discuss the option of taking retaliatory action. After discussing the matter with the Committee, the complaining party may suspend benefits of equivalent effect or, where this is impracticable, impose retaliatory measures of equivalent effect against the party complained against. The retaliatory measures may be imposed until a mutually satisfactory resolution of the dispute is achieved. ${ }^{32}$

- In considering what benefits to suspend or retaliatory measures to impose, the complaining party shall:

- suspend benefits or impose retaliatory measures in the same sector as the measure found to be inconsistent with the Agreement; and

- only if such suspension or imposition would be impracticable or ineffective, suspend benefits or impose retaliatory measures in other sectors covered by the Agreement. ${ }^{33}$

- Upon the request of either of the disputing parties, the Committee can convene a panel, composed of the original panelists, to determine if the measures taken by the retaliating party are manifestly excessive. It can also convene the panel to determine if the actions to resolve the dispute by the party complained against are sufficient or satisfactory. ${ }^{34}$

- The retaliatory measures shall be temporary and only be applied until the party complained against has amended or removed the inconsistent measure or has otherwise taken action to resolve the dispute. ${ }^{35}$

- The measures cannot be inconsistent with the Constitution of Canada. ${ }^{36}$ 


\section{B. PERSON-TO-GOVERNMENT DISPUTE RESOLUTION}

Normally, only governments are granted standing in dispute resolution with respect to intergovernmental agreements. However, at the insistence of several parties to the Agreement and with support from a number of private sector business associations, provisions were included in the Agreement which grant persons limited standing in disputes. A person is defined in the Agreement as a natural person or an enterprise. ${ }^{37}$ For the purposes of dispute resolution, it includes a trade union. ${ }^{38}$

While granting persons standing in dispute resolution is a positive step, the provisions are very complex and the steps to be followed by persons are cumbersome and awkward. It is clear that most governments did not really want to grant persons access and only reluctantly agreed to do so.

For the average company or trade union, the best course of action will probably be political action through lobbying, instead of embarking on dispute resolution. For those brave enough to initiate the processes outlined below, the best course of action would be to persuade a government to initiate proceedings on their behalf. For a person to go through the process directly would take a long time, require patience and money, and yield only the fruit of publicity if the recalcitrant government refused to change its measures.

How would a person embark on the dispute resolution process? The procedures are outlined in Figure 2, and like those for government-to-government disputes, consist of four steps:

- Initiation of procedures;

- Using procedures in a sector chapter;

- Following procedures in chapter 17 ;

- Implementation and enforcement.

38 See ibid., art. 1711.6 which states that "[f]or the purposes of this Part, 'person' as defined in Article 200 (Definitions of General Application), includes a trade union as recognized by the applicable legislation of a Party." 


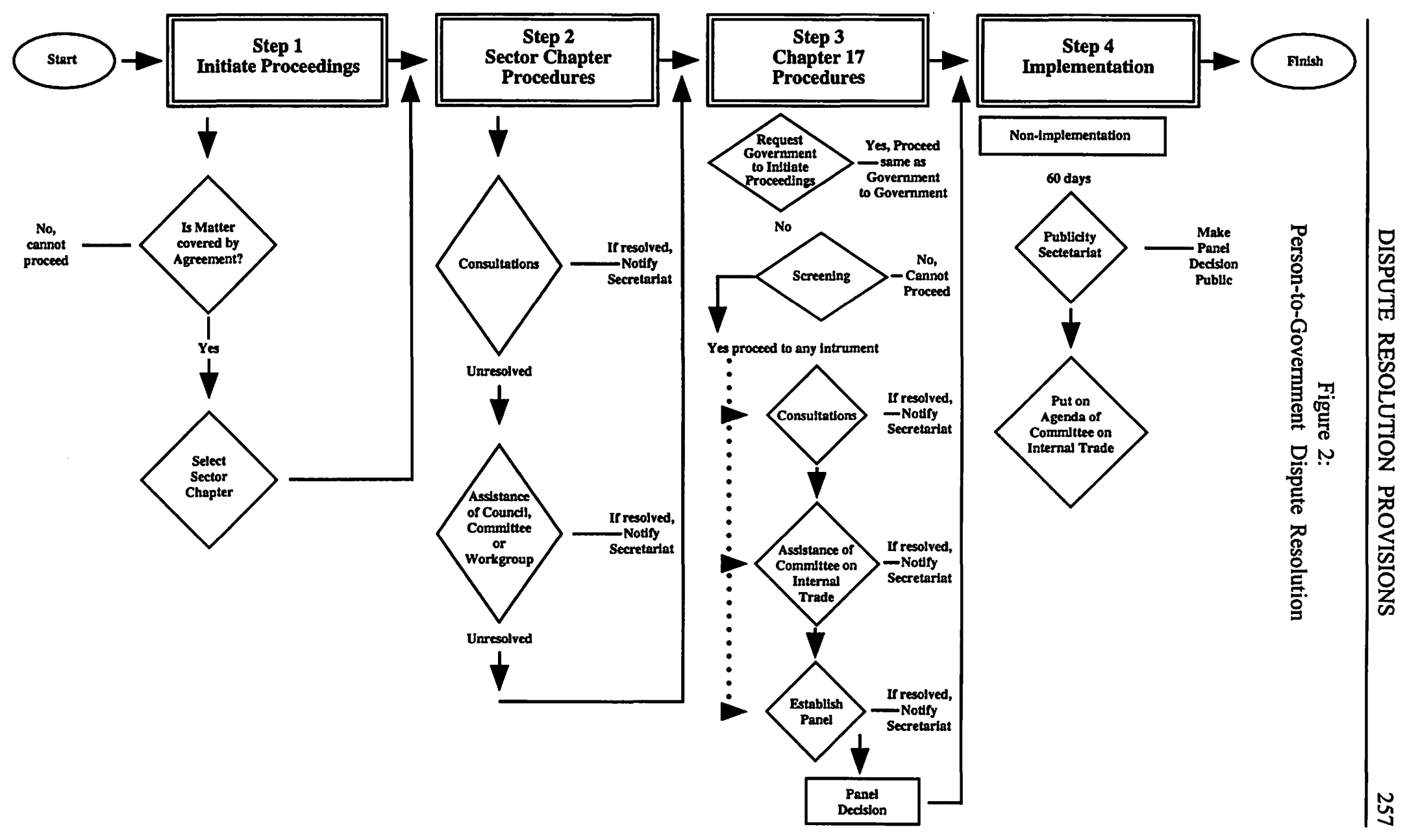




\section{Step 1: Initiation of Procedures}

A person would initiate proceedings in a fashion similar to a government. First, it must be determined if the matter in question is covered by the Agreement, and then a decision must be made under which sector chapter to proceed.

Unlike a government, it appears that a person is not required to notify the Secretariat of the applicable chapter and the matter. The person needs only to notify the party complained against and proceed immediately to the procedures in the chosen chapter.

\section{Step 2: Using Procedures in Sector Chapter}

The procedures noted above with respect to governments would apply for persons. This is an important step, since it must be completed before a person can ask a government to initiate proceedings on his behalf.

\section{Step 3: Chapter 17 Procedures}

If following the procedures in the chosen sector chapter fails to resolve the dispute, a person may initiate proceedings under chapter 17. Unlike governments, which can choose to go directly to consultations, request the assistance of the Committee on Internal Trade or request that a panel be established, persons must go through two preliminary stages. First, a person may request a party to initiate proceedings on its behalf. Second, if the party refuses this request, but the person wants to proceed on his own, the person must undergo screening.

\section{a. Requesting a Party to Initiate Proceedings}

Article 1711 states that a person may request that a party to the Agreement with which it has a substantial connection initiate dispute resolution proceedings on the person's behalf. To make the request, a person must meet three criteria:

- the request must be in writing and specify the matter complained of;

- the processes in the sector chapter must have been exhausted; and

- the person may be required to exhaust all administrative remedies.

The party to the Agreement must decide within thirty days whether to initiate proceedings on behalf of the person and within that period must provide written notice of its decision to the person. If a party chooses to initiate proceedings, it must do so within ten days after providing notice to the person. If it chooses not to initiate proceedings, it must include reasons for its decision in the notice. ${ }^{39}$ 
If the party to the Agreement agrees to initiate proceedings on behalf of the person, the case becomes a government-to-government case and the procedures noted above under government-to-government would be followed. What if, however, the government rejects the request? A person could proceed on his own, but first he would have to be subjected to screening.

Should a person request a party to initiate proceedings? The answer is yes. It would be one way of obtaining an ally in the dispute and it would simplify procedures for the person, since governments have more options and flexibility under the Agreement. However, several caveats should be put on the "yes."

First, if it were possible, this request should be made at the very beginning of the process instead of at this point. It would be useful to know right up front if a government would be willing to take up the case on the person's behalf. If a government were willing to take up the case, a person's task would be much easier. Unfortunately, however, the Agreement is structured so that a person must go through a sector chapter and then come up to chapter 17.

Second, a person must carefully assess which government to ask to initiate proceedings. Under the article, a person must have a "substantial connection" with the party being approached. This is defined in different ways for the provinces and the federal government. A province is deemed to have a substantial and direct connection with a person if: ${ }^{40}$

a) the person resides or carries on business in the Province;

b) the person has suffered an economic injury or denial of benefit; and

c) the consequence of that economic injury or denial of benefit are being felt in the province.

The federal government is deemed to have a substantial and direct connection with the person if the person has suffered an economic injury or denial of benefit as a result of being treated inconsistently within the Agreement by reason of: ${ }^{41}$

a) its status as a federally-constituted entity; or

b) its carrying on business that is a work, undertaking, business or service under federal regulatory authority.

It is quite possible that a person has a substantial connection with several governments. In such cases, having decided against which government to lodge a complaint, the person will have to assess which other government is most likely to help it take a case against the targeted government. Among other things, this would require 
an analysis of the political landscape to determine how the relations between various governments are and what factors may be affecting those relationships.

\section{b. Screening}

Screening was apparently included in the chapter to satisfy the concerns of jurisdictions who were afraid the private sector would use the dispute resolution procedures to harass governments.

Each party is to appoint an individual screener before the date of entry into force of the Agreement. ${ }^{42}$ The screener is to be independent of government and capable of making an independent decision on the merits of requests from persons who want to initiate proceedings.

The role of the screener is twofold. First, the screener reviews requests to determine whether a person should be permitted to commence dispute resolution proceedings. In deciding whether a person should be permitted to commence proceedings, the screener shall take into account: ${ }^{43}$

a) whether the complaint is frivolous or vexatious;

b) whether the complaint has been instituted merely to harass the party complained against; and

c) whether there is reasonable case of injury or denial of benefit to the person or, in the case of a trade union, injury or denial of benefit to its members.

The second role of the screener is to determine the sector chapter under which a person shall proceed.

Should a person go through screening? Yes, if a person is determined to go to the next step. A person cannot proceed to the next step without approval of the screener. However, a careful assessment should be made of the pros and cons of proceeding. In many cases the pains will be greater than the rewards. There are several considerations to take into account:

- A person would be undergoing screening by the same party that just rejected the request to it to initiate a case on his behalf. Although the screener is independent of government, the screener has been appointed by the same party. Is there any more likelihood that the screener would allow the case to proceed?

- Having just finished consultations at the sector level, it is debatable if it is worth going through screening merely to engage in further consultations. 
- The major reason for wanting to proceed would be to request the assistance of the Committee on Internal Trade or to request that a panel be established. A person would have to carefully assess what could be obtained through these instruments. All things considered, a person should usually proceed directly to requesting that a panel be established.

c. Consultations, Assistance of Committee on Internal Trade, Panel

\section{i. Consultations}

A person is greatly restricted in his ability to engage in consultations. ${ }^{44}$ Whereas governments can consult on any matter, a person can only request consultations with the party complained against respecting the complaint approved by the screener.

\section{ii. Assistance of Committee on Internal Trade}

Both governments and persons appear to have the same type of access to the assistance of the Committee on Internal Trade. ${ }^{45}$ On the surface, it appears that the person should be able to obtain adequate assistance. However, careful consideration must be given to the political dynamics. The Committee is a group of peers and the party complained against will have its minister at the table. The person complaining in this context is an outsider. He will be heard, but his presence is transitory. All things considered, the best way to approach the Committee is through one of the governments rather than directly.

\section{iii. Panel}

For the most part, provisions for establishing a panel in government-to-government and person-to-government cases are identical. The major difference appears to be in the terms of reference of the panel. Whereas in government-to-government cases the terms of reference are flexible, the Agreement is categorical with respect to person-togovernment cases. The terms of reference for the panel in these cases shall be to examine whether the actual measure at issue is inconsistent with the Agreement. ${ }^{46}$

\section{Step 4: Implementation of Panel Report and Enforcement}

Implementation of a panel report for a person-to-government case is similar to that for government-to-government, except for the awarding of costs.

On receipt of the panel report, the person and the party complained against shall agree on a resolution of the dispute which shall normally conform with the recommendations of the panel. ${ }^{47}$ Wherever possible, the resolution of the dispute shall 
be the non-implementation, removal or amendment of the measure that is inconsistent with the Agreement. ${ }^{48}$

Where a party has not complied within sixty days, the only recourse is publicity. The Secretariat shall make the panel report public, and the matter shall be added to the Committee on Internal Trade's agenda for its annual meeting, where it shall remain until the matter is resolved. ${ }^{49}$

Whereas in government-to-government cases the parties are expected to share the costs of proceedings, in a person-to-government case, if a person wins he can have costs awarded. The award is at the discretion of the panel and determined in accordance with Annex 1718.3 of the Agreement.

\section{PART THREE: ASSESSMENT OF DISPUTE RESOLUTION PROVISIONS}

Overall, the dispute resolution provisions of the Agreement are understandable and sensible. Notwithstanding the contrasting views at the negotiating table and the complexity of the negotiations, the government-to-government dispute resolution provisions are generally well thought out, well constructed and well integrated. I do not have any major comments with respect to them.

Unfortunately, the person-to-government provisions are problematic. One could reasonably expect these provisions to be difficult, given the conflicting views at the negotiating table and the reluctance of some of the parties to allow the private sector access to dispute resolution. Even accounting for these factors, however, the procedures are unnecessarily awkward and complex.

What are the problems and how could they be addressed?

- First, the underlying premises on which the person-to-government provisions are based are questionable. It is presumed that persons would have interests which are vastly different from governments and that they would bring vexatious actions intended to harass governments. In fact, there is little evidence to support such a view. The better view is that the private sector, like governments, is interested in liberalizing trade and would not spend its money merely to harass governments. Generally, companies want to have long-term relationships with governments and they will not lightly begin action to disrupt that relationship.

It may be difficult to change perceptions, but the outcome of such change could be dramatic. For instance, if it were assumed that the private sector is not bent on harassing governments, screening may not be required. At a minimum, two of the factors the screener must take into account (whether the complaint is frivolous or vexatious, and whether the complaint has been 
instituted to harass the party complained against) could be eliminated. At best, these are subjective factors which would be difficult to substantiate and assess.

- Second, the purpose of screening is rather confused. The purpose appears to be twofold. First, to discourage persons from initiating complaints that are frivolous or vexatious and intended to harass governments. Second, to determine if a person should be allowed to proceed, based on his having a reasonable case of injury or denial of benefits. I would suggest that, of these two purposes, the only legitimate one is to determine if a person has a legitimate case and should be allowed to proceed.

- Third, the sequence of the procedures is awkward. A person is required to initiate proceedings through the sector chapters. Having done that, before commencing chapter 17 proceedings he is required to request a party to the Agreement to initiate proceedings on his behalf. If the party to the Agreement rejects the request but the person still wants to proceed, he is required to undergo screening. One of the roles of the screener is to choose the sector chapter under which the person should proceed. Such a process is open to the strong possibility that the person would have to go through some steps twice if the screener were to send him back to a sector process.

The simple solution to this problem is to move the screening and the request for a government to initiate proceedings to the start of the process. Screening should be done first. This way, if it is established that a person has a legitimate case, a person can decide whether to proceed directly or whether to request a government to initiate a case. In addition, a government would have an independent assessment of the merits of the complaint and can use it as one factor in its determination of whether to or not initiate proceedings on behalf of a person.

- Fourth, a person is required to go through a tedious, expensive process to show that the denial of benefits caused him injury, but he gets nothing for it. At most, he gets the costs of his action reimbursed. A party to the Agreement, in contrast, is required to remove or amend the measure which is inconsistent with the Agreement, but if it refuses to act it will be subject only to publicity. Some parties suggested that more discipline than this is required for offending governments. I agree, and suggest that the parties reconsider whether damages should be awarded to persons who suffered injury.

\section{CONCLUSION}

The Agreement on Internal Trade is a landmark agreement. It contains interesting and innovative dispute resolution provisions. The government-to-government provisions are appropriate for solving disputes among governments. The person-to-government dispute resolution provisions are a very good start. They reflect the state of play during the negotiations. However, they are based on a number of questionable premises and 
they are cumbersome. They could be improved and streamlined so that persons could more effectively take advantage of them to solve disputes. 
Table 1: Sector Chapter Provisions on Dispute Resolution

\begin{tabular}{|c|c|c|c|c|}
\hline Chapter & Article & Type of Provision & $\begin{array}{l}\text { Point of Referral } \\
\text { to Chapter } 17\end{array}$ & $\begin{array}{c}\text { Group Available } \\
\text { to Assist in } \\
\text { Resolving Matter }\end{array}$ \\
\hline 5: Procurement & $\begin{array}{l}508.2 \\
513 \\
514\end{array}$ & $\begin{array}{l}\text {-Factors to take into } \\
\text { account for dispute } \\
\text { on procurement } \\
\text { excluded from } \\
\text { application of Chapter } \\
\text {-Bid Protest } \\
\text { Procedures - Province } \\
\text {-Bid Protest } \\
\text { Procedures - Federal } \\
\text { Government } \\
\end{array}$ & & \\
\hline 6: Investment & $\begin{array}{l}614 \\
\\
\\
\text { Annex } \\
608.3 .11\end{array}$ & $\begin{array}{l}\text { - Consultations } \\
\text {-Consultations }\end{array}$ & $\begin{array}{l}\text {-If matter is not } \\
\text { resolved within } \\
90 \text { days after } \\
\text { receipt of request } \\
\text { for consultations } \\
\text {-If matter is not } \\
\text { resolved within } \\
90 \text { days after } \\
\text { receipt of request } \\
\text { for consultations }\end{array}$ & $\begin{array}{l}\text {-Working Group } \\
\text { on Investment } \\
\text {-Working Group } \\
\text { on Investment }\end{array}$ \\
\hline 7: Labour Mobility & 711 & -Consultations & $\begin{array}{l}\text {-If matter not } \\
\text { resolved within } \\
90 \text { days of receipt } \\
\text { of request }\end{array}$ & \\
\hline $\begin{array}{l}\text { 8: Consumer- } \\
\text { Related Measures } \\
\text { and Standards }\end{array}$ & $8 \times x$ & $\begin{array}{l}\text { - Consultations (Only } \\
\text { a draft article was } \\
\text { available at time of } \\
\text { writing) } \\
\text {-Committee of } \\
\text { Ministers to resolve } \\
\text { matter through } \\
\text { conciliation or } \\
\text { mediation }\end{array}$ & $\begin{array}{l}\text {-If matter not } \\
\text { resolved within } \\
90 \text { days of being } \\
\text { referred to the } \\
\text { Committee of } \\
\text { Ministers } \\
\text { (Note: this would } \\
\text { be } 150 \text { days after } \\
\text { the complaint was } \\
\text { initiated) }\end{array}$ & $\begin{array}{l}\text {-Committee on } \\
\text { Consumer Related } \\
\text { Measures and } \\
\text { Standards } \\
\text {-Committee of } \\
\text { Ministers } \\
\text { Responsible for } \\
\text { Consumer Related } \\
\text { Measures and } \\
\text { Standards }\end{array}$ \\
\hline $\begin{array}{l}\text { 9.: Agricultural and } \\
\text { Food Goods }\end{array}$ & 906 & -Consultations & $\begin{array}{l}\text {-No provision for } \\
\text { referral to Chapter } \\
17\end{array}$ & $\begin{array}{l}\text {-Trade Policy } \\
\text { Committee }\end{array}$ \\
\hline
\end{tabular}




\begin{tabular}{|c|c|c|c|c|}
\hline Chapter & Article & Type of Provision & $\begin{array}{l}\text { Point of Referral } \\
\text { to Chapter } 17\end{array}$ & $\begin{array}{l}\text { Group Available } \\
\text { to Assist in } \\
\text { Resolving Matter }\end{array}$ \\
\hline $\begin{array}{l}\text { 10: Alcoholic } \\
\text { Beverages }\end{array}$ & 1009.1 & $\begin{array}{l}\text { - Complaints } \\
\text { procedures for } \\
\text { producer of a party }\end{array}$ & $\begin{array}{l}\text {-If matter is not } \\
\text { resolved within } \\
90 \text { days of } \\
\text { complaint being } \\
\text { lodged }\end{array}$ & \\
\hline & 1009.2 & $\begin{array}{l}\text {-Consultations by } \\
\text { Parties }\end{array}$ & $\begin{array}{l}\text {-If matter is not } \\
\text { resolved within } \\
60 \text { days of request } \\
\text { for consultations }\end{array}$ & \\
\hline $\begin{array}{l}\text { 11: Natural } \\
\text { Resources } \\
\text { Processing }\end{array}$ & $\begin{array}{l}1103 \\
\text { Annex } \\
1103.2\end{array}$ & -Consultations & $\begin{array}{l}\text {-After exhausting } \\
\text { process outlined } \\
\text { in Annex } 1103.2 \\
\text { ( } 180 \text { days after } \\
\text { delivery of } \\
\text { request for } \\
\text { consultations) }\end{array}$ & $\begin{array}{l}\text {-Working Group } \\
\text { on Natural } \\
\text { Resources } \\
\text { Processing }\end{array}$ \\
\hline 12: Energy & \multicolumn{4}{|c|}{ Chapter is being negotiated. Provisions not available at time of writing } \\
\hline $\begin{array}{l}\text { 13: } \\
\text { Communications }\end{array}$ & \multicolumn{4}{|c|}{$\begin{array}{l}\text { No dispute settlement provisions. However, a Communications Committee is } \\
\text { established which would provide a forum for parties to consult on issues } \\
\text { respecting the Chapter }\end{array}$} \\
\hline 14: Transportation & 1412 & -Consultations & $\begin{array}{l}\text {-If consultations } \\
\text { have not begun } \\
\text { within } 60 \text { days of } \\
\text { request; or if } \\
\text { Assistance of the } \\
\text { Council of } \\
\text { Ministers has not } \\
\text { resulted in a } \\
\text { mutually } \\
\text { satisfactory } \\
\text { resolution within } \\
90 \text { days after } \\
\text { request for } \\
\text { assistance }\end{array}$ & $\begin{array}{l}\text { - Council of } \\
\text { Ministers } \\
\text { Responsible for } \\
\text { Transportation }\end{array}$ \\
\hline $\begin{array}{l}\text { 15: Environmental } \\
\text { Protection }\end{array}$ & $\begin{array}{l}1510 \\
\text { Annex } \\
1510.1\end{array}$ & $\begin{array}{l}\text {-Consultations and } \\
\text { assistance of Council } \\
\text { of Ministers of } \\
\text { Environment }\end{array}$ & $\begin{array}{l}\text {-If not resolved } \\
\text { within } 50 \text { days } \\
\text { after request for } \\
\text { Assistance of } \\
\text { Council of } \\
\text { Ministers }\end{array}$ & $\begin{array}{l}\text { - Canadian Council } \\
\text { of Ministers of the } \\
\text { Environment }\end{array}$ \\
\hline
\end{tabular}

